This item was submitted to Loughborough's Research Repository by the author.

Items in Figshare are protected by copyright, with all rights reserved, unless otherwise indicated.

\title{
Production analysis applied to work improvement
}

PLEASE CITE THE PUBLISHED VERSION

http://dx.doi.org/10.1680/iicep.1984.1190

\section{PUBLISHER}

(C) ICE

\section{VERSION}

VoR (Version of Record)

\section{PUBLISHER STATEMENT}

This work is made available according to the conditions of the Creative Commons Attribution-NonCommercialNoDerivatives 4.0 International (CC BY-NC-ND 4.0) licence. Full details of this licence are available at: https://creativecommons.org/licenses/by-nc-nd/4.0/

\section{LICENCE}

CC BY-NC-ND 4.0

\section{REPOSITORY RECORD}

Broomfield, J.R., Andrew D.F. Price, and Francis C. Harris. 2019. "Production Analysis Applied to Work Improvement". figshare. https://hdl.handle.net/2134/23397. 


\title{
TECHNICAL NOTE 415
}

\section{Production analysis applied to work improvement}

\author{
J. R. BROOMFIELD, MSc* \\ A. D. PRICE, BSc $\dagger$ \\ F. C. HARRIS, BEng, MSc, PhD, MICE, MCIOB $\ddagger$
}

\begin{abstract}
This Note provides an introduction to the research being carried out in the Department of Civil Engineering at Loughborough University and funded by the Science and Engineering Research Council (SERC), into Work Study applied to construction work. The emphasis is directed towards ascertaining site efficiency factors and the methods of determining operation times. In subsequent Notes, the measuring techniques will be explained in detail and examples of typical data for use in estimating and cost control described.
\end{abstract}

\section{Introduction}

Until quite recently the Construction Industry had, in general, been well supplied with work from both public and private clients. In the foreseeable future, however, the formerly high steady growth in such volume may not be sufficient to provide all firms with a full order book, and more attention to production efficiency must inevitably follow if profits are to be maintained. ${ }^{1}$ In this more competitive environment the ultimate goal must clearly be to reach almost irreducable cost levels. Even now certain trends are emerging-for example, firms are beginning to offer guaranteed maximum price contracts, self-financing highways, and homes rather than houses.

2. While developments of this sort will be a gradual process, research work undertaken in the Department of Civil Engineering at Loughborough University of Technology, and funded by the Science and Engineering Research Council $\left(\right.$ SERC) ${ }^{2}$ hopes to be in the vanguard of this movement. Currently, investigations are taking place to ascertain the most appropriate methods of determining realistic output levels of labour and plant in expectation of a greater emphasis being given to seeking the causes and remedies of production inefficiencies. This Note describes this work, and aims to direct attention towards a positive attitude to work improvement and away from the traditional view of work study, as being largely an inconvenient interference from head office.

\section{Establishing production data}

3. In the UK, it would appear that thus far only the SERC is funding Work

Written discussion closes 15 November 1984; for further details see p. (ii).

* Head of Corporate Planning and Development, Harry Stanger Ltd, Elstree.

$\dagger$ Research Assistant, Department of Civil Engineering, Loughborough University of Technology.

‡ Senior Lecturer, Department of Civil Engineering, Loughborough University of Technology. 
Study research of national construction. At this stage research is primarily concerned with developing work measurement techniques with industry to obtain reliable output data for the planning and costing of construction work. The major divisions of construction activity being investigated for output measurement include: bulk excavation, trench excavation, shoring trenches, excavation for footings, rebar fixing, formwork, concreting, pipelaying, sheet piling, road paving, structural steel erection, and precast concrete erection. Ultimately it is proposed to incorporate files of standard output data in the disc-file libraries of established costing and planning software.

4. The Work Study Research Group has enjoyed a certain freedom of access to the records of up to twenty years of construction Work Study effort by some organizations within the public and private sectors, but have been dismayed by the huge variation in data collection techniques. This probably has something to do with the exclusive organization of each construction project, and with making sure that records are of limited use to fellow bidders, competitors and customers. So it is clear that such data gathered from various sources are unlikely to be comparable unless they have been standardized by some unified approach. It seems that the British situation in this respect is quite disorganized when compared with others

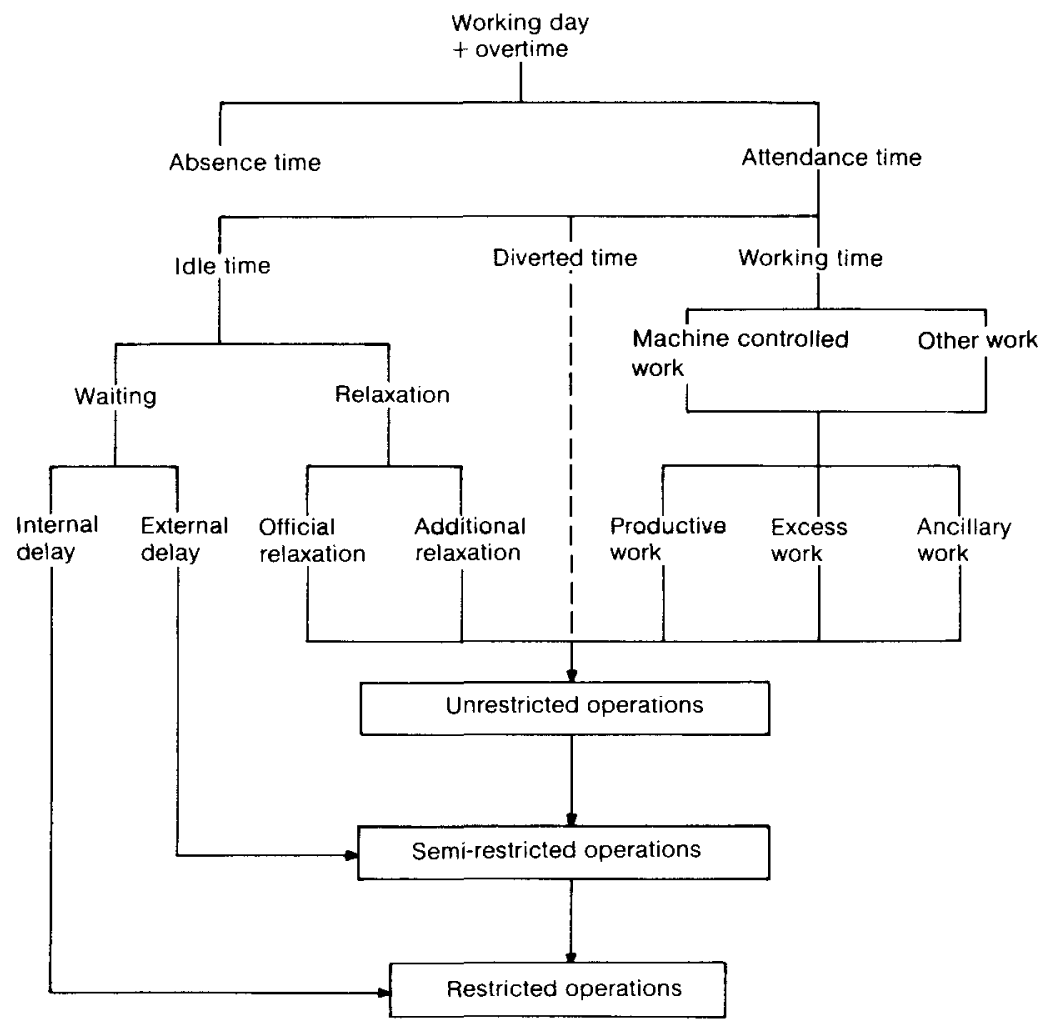

Fig. 1. Classification of work and idle times 


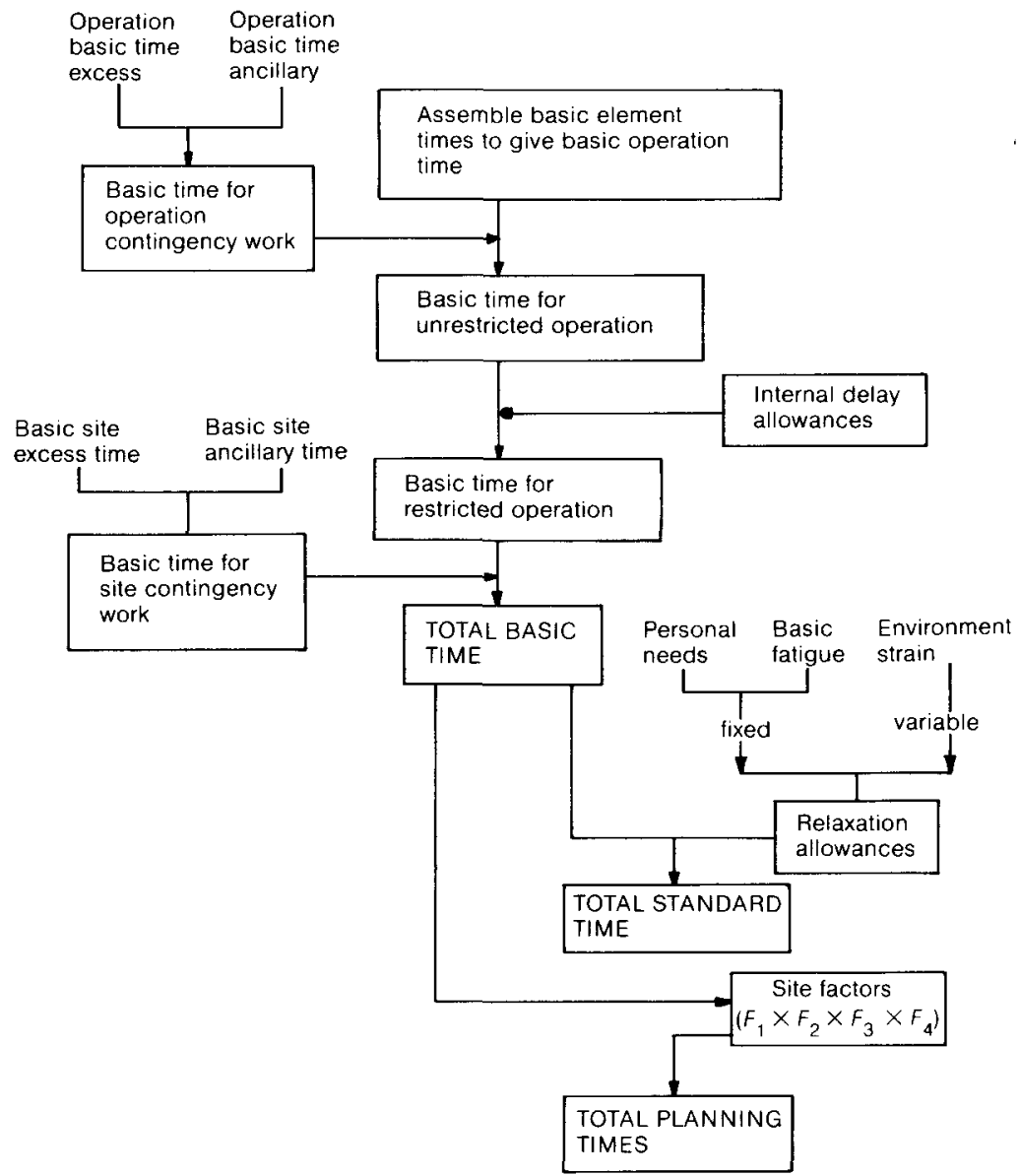

\section{Fig. 2. Build up of time standards}

on the continent. For example, constructors in the Netherlands have formed a progressive co-operative with the charter to provide a pool of output times linked to construction methods. These are updated and published monthly by the journal Bouwkosten to provide guidance for the industry and its customers.

5. With a similar objective in mind, we have developed a site efficiency measurement technique by merging three tried and tested work measurement systems from manufacturing, i.e. Activity Sampling combined with cumulative timing and worker rating to establish the standards for construction operations. It is emphasized, however, that the portability of Work Study data between sites and companies will not happen merely because they have been standardized. Libraries of output data must also be capable of being made relevant to each unique situation. Time standards for each category of construction output therefore would have to include three components: the basic time; relaxation allowances; and contingency allowances. 
6. The basic time is the normal time for a qualified worker to carry out a specific job at a brisk pace of working. This pace of working is unreasonable to expect throughout the working day without rest periods. The answer to the question of what relaxation and contingency allowances should be provided is not simple. This has led to a meticulous breakdown of the working day as shown in Fig. 1 and indicates that construction work often presents ample opportunities for rest during built-in waiting periods.

7. This analysis, coupled with the variation of output on site, confirmed the need to include other factors in the build-up of time standards as shown in Fig. 2. (A description of the terms used in the Figure is given in Table 1).

\section{Table 1. Work contingencies}

(1) Basic excess time

This is the additional work which is caused by the deviation from the standard method and can be attributed to either the operation or the site. (e.g. the time spent carrying reinforcement which has been unloaded in the wrong area).

(2) Basic ancillary time

This is the necessary work which is part of an operation (e.g. maintenance of plant), or site organization (e.g. walking to canteen) and cannot appropriately be classified as productive.

\section{Lost time}

(1) Internal delays (interference)

This is the time when the operative is prevented from working because of the nature of the task, and is generally of a low order when dealing with site operatives as there is invariably some other work (which is part of that operation) to carry on with. Internal delays become significant when machines are involved, where the operatives or machine may have enforced idleness because of the working cycle. This is called a restricted operation. (e.g. banksman waiting for machine to excavate).

(2) External delays (waiting)

These occur for a wide variety of reasons and are mainly caused by poor site organization. They lie outside the control of those involved with the operation under study. (e.g. waiting for materials).

(3) Relaxation

When work is available the only viable reason for not doing it is the motivation of the operative. However, official relaxation allowances are normally provided but it should be realized that in practice these are inter-related to other periods of lost time.

(4) Work rate

The main cause in variation of work rate is the skill of the operative. As most operations occur on a regular basis and are performed by men with good experience, there is generally little variation in rating levels. However, when an operation of a complex nature occurs, the variation can be very high because the operative is in a learning situation.

(5) Extra breaks

This is the time the worker is not available for work as a result of additional breaks, early finishes or late starts, and is related to low motivation but is to a large extent within the control of the management.

(6) Official breaks

The relationship between work contingencies, lost time, types of operation and the working day are shown in Figs 2 and 3. 
8. The need for site factors arises from the traditional, but mistaken assumption that much of the variation in output can be traced back to the Work Rate. The Rating system only adjusts the basic time to the extent limited by the pace of working. Obviously the degree of motivation to produce well and quickly varies between workers and their supervisors. Also, it is a function of employment conditions, site regime and weather conditions. Our investigations have repeatedly found that when workers are producing, they work at more or less the same pace. Site efficiency was most readily improved by maximizing the opportunity of all to work. To summarize, the main causes of variation in output were found to be as follows

(a) Internal delay - adds to basic time

(b) Work Rate $-F_{1}$

(c) Waiting for Work or Materials (includes mechanical breakdown) $-F_{2}$

(d) Extended Breaks (including late starts and early knock-offs) $-F_{3}$

(e) Relaxation (when work is available) $-F_{2}$

9. The first cause is accounted for by adding the interference time from the degree of operational restriction (e.g. waiting for hoist platform) to the basic times of elements comprising the operation. This is then called the Total Basic Time. All of the other causes of lower output were found to be largely motivational or organizational problems over which all managers should claim to have some control.

10. These so-called site factors must be reckoned as part of each working day. The working day has therefore been related to the basic times, with site factors $\left(F_{n}\right)$ for elements of construction work as follows

$$
\text { Working Day }=\text { Total Basic Times } \frac{F(\text { Total })}{\left[\left(F_{1}\right)\left(F_{2}\right)\left(F_{3}\right)\left(F_{4}\right)\right]}
$$

where

$$
\begin{aligned}
& F_{1}=\frac{\text { Working Time }}{\text { Total Basic Time }}=\text { Work Rate } \\
& F_{2}=\frac{\text { Attendance Time }}{\text { Working Time }}=\text { Idle Time (items }(c) \text { and }(e) \text { above) } \\
& F_{3}=\frac{\text { Working Hours }}{\text { Attendance Time }}=\text { Extended Breaks } \\
& F_{4}=\frac{\text { Working Day }}{\text { Working Hours }}=\text { Official Breaks }
\end{aligned}
$$

11. A schematic view of this is shown in Fig. 3. Typically, site factors in total $\left(F_{\text {(total) }}\right)$ have been found to vary between 1.2 and 2.5 depending upon the site and especially the type of work. Thus the site efficiency is simply the reciprocal of the site factor. In other words from the site factors given, efficiency factors vary from $40 \%$ to $80 \%$.

12. As can be appreciated, dealing in $F_{(\text {total })}$ alone does not necessarily help solve the problem of identifying the cause of poor efficiency. This aspect is forming part of a further study, ${ }^{3}$ which will be reported at a later date, but the four constituent factors indicate where there are opportunities for improvement. 


\section{BROOMFIELD, PRICE AND HARRIS}

\section{Encouraging the use of efficiency factors}

13. In practice, Work Study is initially likely to be of most interest if directed towards work improvement on particular sites. It is only when it becomes clear that better methods of working are possible that feedback data will begin to be pooled for subsequent use.

14. Our investigations have demonstrated that the greatest impact is first obtained by producing figures showing the quite low levels of efficiency typical on construction sites (i.e. site factors). Thereafter, the steady education of all concerned should gradually be implemented along the following lines.

\section{Establish current levels of effective time}

(a) Build a team of like-minded managers who accept that there must be a better way and want to find it.

(b) Aid development of a site efficiency measurement system relevant to the company.

(c) Provide emphasis effectively to communicate the site efficiency measurement technique on site.

(d) Develop a list of operational cost codes for later use as a company standard.

Encourage those in control to be aware of the opportunities for improvement

(a) Prepare aids for stunning visual impact showing proportion and type of ineffective times typical of current operations.

(b) Invite participating site managers to attend seminars on work improvement and prompt discussion for reducing ineffective time.

(c) Gain consensus on the need to enhance appreciation of site efficiency and win confidence in the proposed measurement system.

(d) Introduce, explain and issue the site efficiency measurement procedure.

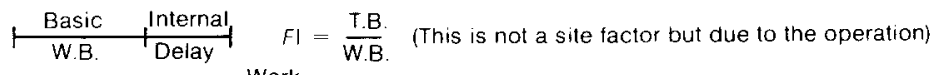
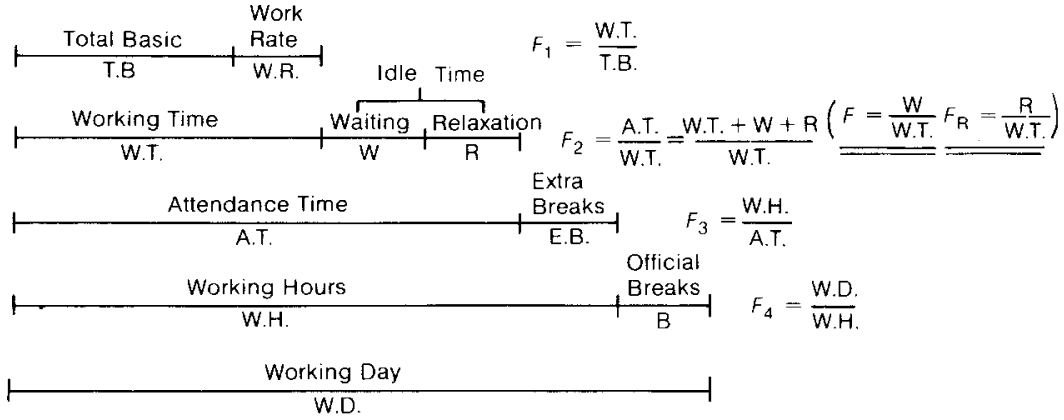

The relationship between the working day and total basic times can therefore be expressed as: Working Day $=$ Total Basic Time $\times F_{1} \times F_{2} \times F_{3} \times F_{4}$

Fig. 3. Interference and site factors 
15. Considerable improvements could accrue from this programme alone. Subsequent steps might then be taken to extend the studies to embrace the preparation of time standards for construction operations with the ultimate link to estimating, financial incentive schemes and budgetary and cost control.

\section{Conclusions}

16. The results of our investigations indicate that Work Study techniques can be adapted to meet the variations of most sites, projects and companies, and so provide realistic output data for estimating and planning purposes. The site factors are the key to the new found portability, giving the possibility of isolating basic times for operations and also of increasing the opportunities to use the computer in data handling and analysis. This latter aspect is particularly exciting with the recent introduction of the portable personalised microcomputer such as the EPSON or APRICOT models which can be carried on site. In this way current data can be immediately included to update studies. In a subsequent article the procedures for achieving these objectives, together with examples of site efficiency factors and production times, labour and plant requirements for typical construction operations will be described.

\section{Future work}

17. As far as the future is concerned, more people working independently in industry, but pooling their information in a standardized form, would provide a forum for an exchange of information on methods of working with the hope of improving productivity. We at Loughborough are keen to encourage this to happen and will continue to seek and promote research into Work Study. In the short term we see a need to investigate the influence on productivity of gang size, sub-contract labour, direct labour, materials handling methods, and so on; the list is almost inexhaustible. We would be pleased to exchange information with other investigators and publish findings on a regular basis.

\section{References}

1. BROOMFIELd J. Construction work study in perspective. MSc project report, Department of Civil Engineering, Loughborough University of Technology, September 1983.

2. HARRIS F. C. (Investigator). An evaluation of production output for construction labour and plant. SERC Research Grant GR/B 55138, 1981-84.

3. WALlACE W. A. Management organisation and operative performance. MSc project report, Department of Civil Engineering, Loughborough University of Technology, 1983.

\section{Bibliography}

4. Price A. and Harris F. C. Activity Sampling applied to concrete work. Internal paper, Department of Civil Engineering, Loughborough University of Technology, June 1983.

5. SHORT N. R. A comparison between trench support systems and traditional methods of shoring. BSc project report, Department of Civil Engineering, Loughborough University of Technology, April 1981. In addition, a paper jointly with F. C. Harris published in Building Technology and Management, April 1983, 21, No. 4.

6. British Water Ways Board. Piling and Dredging Bonus Schemes, 1982.

7. Transport and Road Research Laboratory. Coddle and Cossit work study data, stored on tape, on road surface for construction, 1973-82.

8. JoINT INDUSTRY BOARD FOR THE ElECTRICAL CONTRACTING INDUSTRY. National Library of Work Study Data, 1973. 
9. Department of Transport. The Rate System. Highway Engineering Computer Branch, Department of Transport, 1979.

10. PARMenter B. S. Estimating resources and costs for highway works-development of the Rate System. Transport and Road Research Laboratory, Crowthorne, TRRL Report 957, 1979.

11. Cornwall County Council Highways Department. Composite Work Values, Highways Construction and Maintenance, August 1982.

12. Lincolnshire County Council. Standard Minute Values, July 1978.

13. Stichting arbeidstechnisch onderzoek bouwnijverheid (SAOB). Richttijden voor bouwactiviteiten. Standard times for building operations used in Holland. Ede. Holland, 1978.

14. Byggforbundet. Method Och Data. Standard times for building operations used in Sweden. Sweden, 1973.

15. Loughborough UNIVERSITY of TEChNOLOGY. Estimating and Planning Data for construction work. Disc File Storage. Department of Civil Engineering, Loughborough University of Technology, 1983-84.

16. HARRIS F. C. and McCAFFER, R. Modern Construction Management. Granada (2nd edn), 1983.

17. Ashwor TH A. The source, nature and comparison of published cost information. Building Technology and Management, March 1980, 18, No. 3. 